NASA/TM-1999-209656

(2)

\title{
Solar Stirling for Deep Space Applications
}

Lee S. Mason

Glenn Research Center, Cleveland, Ohio 
Since its founding, NASA has been dedicated to the advancement of aeronautics and space science. The NASA Scientific and Technical Information (STI) Program Office plays a key part in helping NASA maintain this important role.

The NASA STI Program Office is operated by Langley Research Center, the Lead Center for NASA's scientific and technical information. The NASA STI Program Office provides access to the NASA STI Database, the largest collection of aeronautical and space science STI in the world. The Program Office is also NASA's institutional mechanism for disseminating the results of its research and development activities. These results are published by NASA in the NASA STI Report

Series, which includes the following report types:

- TECHNICAL PUBLICATION. Reports of completed research or a major significant phase of research that present the results of NASA programs and include extensive data or theoretical analysis. Includes compilations of significant scientific and technical data and information deemed to be of continuing reference value. NASA's counterpart of peerreviewed formal professional papers but has less stringent limitations on manuscript length and extent of graphic presentations.

- TECHNICAL MEMORANDUM. Scientific and technical findings that are preliminary or of specialized interest, e.g., quick release reports, working papers, and bibliographies that contain minimal annotation. Does not contain extensive analysis.

- CONTRACTOR REPORT. Scientific and technical findings by NASA-sponsored contractors and grantees.
- CONFERENCE PUBLICATION. Collected papers from scientific and technical conferences, symposia, seminars, or other meetings sponsored or cosponsored by NASA.

- SPECIAL PUBLICATION. Scientific, technical, or historical information from NASA programs, projects, and missions, often concerned with subjects having substantial public interest.

- TECHNICAL TRANSLATION. Englishlanguage translations of foreign scientific and technical material pertinent to NASA's mission.

Specialized services that complement the STI Program Office's diverse offerings include creating custom thesauri, building customized data bases, organizing and publishing research results ... . even providing videos.

For more information about the NASA STI Program Office, see the following:

- Access the NASA STI Program Home Page at $h t t p: / / w w w . s t i . n a s a . g o v$

- E-mail your question via the Internet to help@sti.nasa.gov

- Fax your question to the NASA Access Help Desk at (301) 621-0134

- Telephone the NASA Access Help Desk at (301) 621-0390

- Write to: NASA Access Help Désk NASA Center for AeroSpace Information 7121 Standard Drive Hanover, MD 21076 
NASA/TM-1999-209656

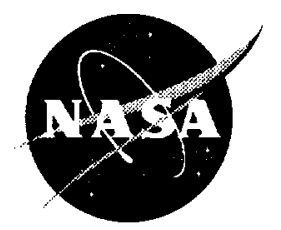

\section{Solar Stirling for Deep Space Applications}

Lee S. Mason

Glenn Research Center, Cleveland, Ohio

Prepared for the

Space Technology and Applications International Forum-2000

sponsored by the American Institute of Physics

Albuquerque, New Mexico, January 30-February 3, 2000

National Aeronautics and

Space Administration

Glenn Research Center 
This report contains preliminary findings, subject to revision as analysis proceeds.

This report is a preprint of a paper intended for presentation at a conference. Because of changes that may be made before formal publication, this preprint is made available with the understanding that it will not be cited or reproduced without the permission of the author.

Available from

NASA Center for Aerospace Information 7121 Standard Drive

Hanover, MD 21076

Price Code: A03
National Technical Information Service 5285 Port Royal Road Springfield, VA 22100

Price Code: A03 


\title{
Solar Stirling for Deep Space Applications
}

\author{
Lee S. Mason \\ National Aeronautics and Space Administration \\ Glenn Research Center \\ Cleveland, $\mathrm{OH} 44135$ \\ Lee.Mason@grc.nasa.gov, (216) 977-7106
}

\begin{abstract}
A study was performed to quantify the performance of solar thermal power systems for deep space planetary missions. The study incorporated projected advances in solar concentrator and energy conversion technologies. These technologies included inflatable structures. lightweight primary concentrators. high efficiency secondary concentrators. and high efficiency Stirling convertors. Analyses were performed to determine the mass and deployed area of multihundred watt solar thermal power systems for missions out to 40 astronomical units. Emphasis was given to system optimization. parametric sensitivity analyses. and concentrator configuration comparisons. The results indicated that solar thermal power systems are a competitive alternative to radjoisotope systems out to 10 astronomical units without the cost or safety implications associated with nuclear sources.
\end{abstract}

\section{INTRODUCTION}

The traditional means to satisfy electrical power requirements for outer planetary space probes is through Radioisotope Thermoelectric Generators (RTGs). RTGs were most recently used on the Galileo. Ulysses and Cassini spacecraft (Kelly, 1997). A joint DOE/NASA program is in place to develop an improved radioisotope power system to replace RTGs. The higher efficiency, Advanced Radioisotope Power System (ARPS) will reduce the required plutonium inventory providing cost and safety benefits (Herrera, 1998). ARPS will utilize an AlkaliMetal Thermal-to-Electric Converter (AMTEC) combined with three General Purpose Heat Source (GPHS) modules to produce 92 watts beginning-of-mission (BOM) in a single power unit. The AMTEC system is projected to offer at least a $2 \mathrm{x}$ improvement in conversion efficiency as compared to conventional thermoelectric converters used in RTGs. This technology is planned for use on future deep space science missions such as Europa Orbiter ('03) and Pluto-Kuiper Express ('04). The projected specific power for the ARPS system is $6.2 \mathrm{~W} / \mathrm{kg}$ and the efficiency is $12.6 \%$ at BOM (Lockheed Martin, 1998)

While reducing the amount of plutonium reduces the health risk associated with an accidental orbital reentry and provides substantial system cost savings, it would be desirable to have a non-nuclear option for deep space missions. However, typical planar photovoltaic (PV) arrays are not effective for space probes traveling beyond Mars ( 1.5 astronomical units, or AU) due to the decrease in insolation with the square of the distance from the sun.

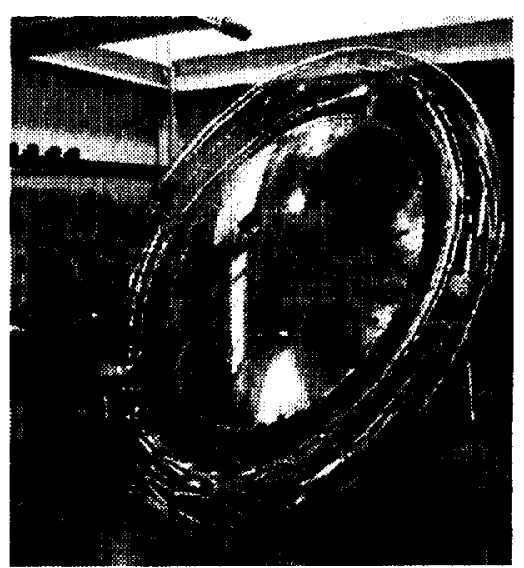

FIGURE 1. Lightweight Inflatable Concentrator (courtesy of SRS Technologies) 
Solar thermal power systems offer a potential alternative. Progress in advanced lightweight concentrator technology provides a necessary first step toward making solar thermal power for deep space missions a viable option. Companies such as L'Garde. SRS Technologies, ILC Dover, United Applied Technologies, and Harris Corporation are developing concepts for large. lightweight solar concentrators. Figure 1 shows an example of a lightweight concentrator using thin-film, inflatable technology. This advanced concentrator technology offers a factor of five improvement in aerial density $\left(\mathrm{kg} / \mathrm{m}^{2}\right)$ over conventional rigid panel concentrators (Mason, 1999). The other key elements to a mass competitive solar power system for far-sun missions are high efficiency secondary concentrators and high efficiency, free-piston Stirling convertors.

Secondary concentrators can provide an increase in the overall geometric concentration ratio as compared to primary concentrators alone. This reduces the diameter of the receiver aperture and the associated infrared cavity losses, thus improving overall efficiency. The use of a secondary concentrator also eases the pointing and surface accuracy requirements of the primary concentrator, making inflatable structures a more feasible option. Typical secondary concentrators are hollow, reflective parabolic cones. Recent studies at Glenn Research Center have investigated the use of a solid, crystalline refractive secondary concentrator for solar thermal propulsion which may provide considerable improvement in throughput efficiency by eliminating reflective losses (Wong, 1999). The refractive secondary concept. shown in Figure 2, also offers the benefit of directed flux tailoring within the receiver cavity via a unique "flux extractor." Such a device has the potential to improve the energy transfer to the Stirling heater head.

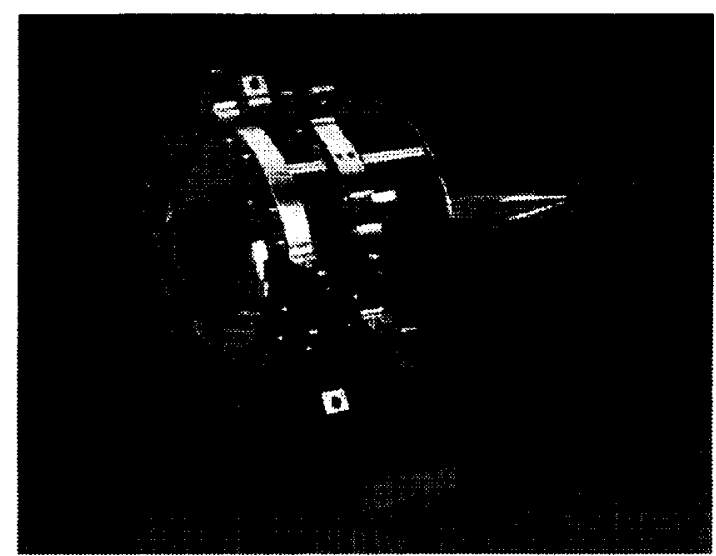

FIGURE 2. Refractive Secondary Concentrator

Stirling convertors have the potential to provide very high thermal-to-electric conversion efficiency. Stirling Technology Company (STC) in Kennewick, Washington has successfully designed, built, and operated free-piston convertors at 10 watts and 350 watts for terrestrial applications. The 350 watt STC convertor is pictured in Figure 3. STC is also developing a space-rated, 55 watt unit for radioisotope applications designed to provide system conversion efficiencies of greater than $24 \%$ (White, 1999). All of these engines share common technology characteristics including flexure bearings and linear alternators. The 10 watt engine has undergone endurance testing to over 50.000 hours in order to demonstrate long life and reliability.

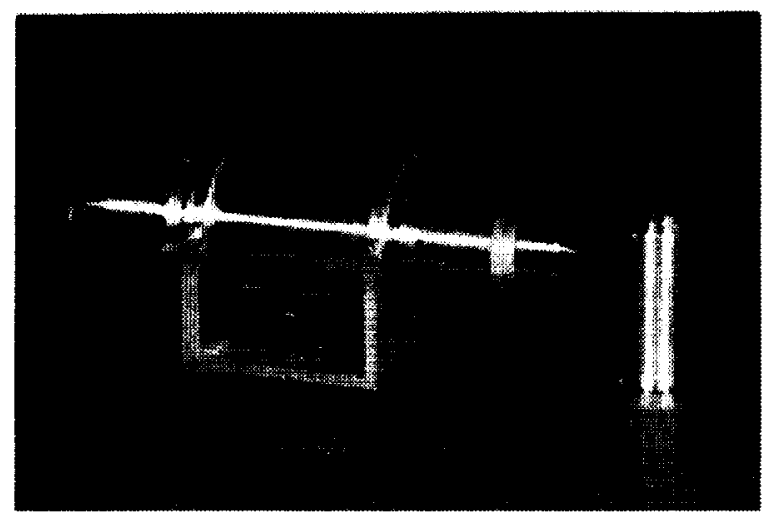

FIGURE 3. Free-Piston Stirling Convertor (courtesy of STC) 


\section{STUDY GROUND RULES}

The overall study objectives were three-fold: 1) determine the feasibility of a solar Stirling power system for deep space missions using various advanced component technologies, 2) determine the key parameters which most influence system performance, and 3) compare system performance to other deep space power system options. The analysis evaluated system mass and deployed area for solar thermal power systems out to Pluto (about $40 \mathrm{AU}$ ).

Some of the key study assumptions are provided in Table 1. A reference electrical power level of 200 watts was chosen as typical of future deep space missions. The insolation and effective sink temperature were varied with distance from the Sun. Several of the component metrics were derived from design work performed by Orbital Sciences Corporation (OSC) in support of a Stirling concept for ARPS (Schock, 1999). The solar heat receiver was envisioned as a simple structure which supports the secondary concentrator and provides a thermal interface to the Stirling heater head, similarly to the GPHS container for the radioisotope Stirling concept. The waste heat radiator and the power management and distribution (PMAD) system were also derived from the OSC Stirling concept. A $10 \%$ system mass margin was included to account for interface structure and other unknowns.

TABLE 1. Key General Assumptions

\begin{tabular}{|l|l|}
\hline Element & Assumptions \\
\hline System & $200 \mathrm{~W}$ electric power. $10 \%$ mass margin \\
\hline Primary Concentrator & $3.5 \%$ pointing loss. $10 \%$ wrinkle loss. $10 \%$ area margin \\
\hline $\begin{array}{l}\text { Secondary } \\
\text { Concentrator }\end{array}$ & $\begin{array}{l}7: 1 \text { concentration ratio. reflective }-85 \% \text { efficiency. } \\
\text { refractive }-95 \% \text { efficiency. passive cooling }\end{array}$ \\
\hline Receiver & No thermal energy storage. $6 \mathrm{~kg} / \mathrm{kWt} .5 \%$ insulation loss \\
\hline Stirling Convertor & $\begin{array}{l}\text { STC design. } 43 \mathrm{~kg} / \mathrm{k} \text { We (includes active balancer). } 2 \\
\text { convertors } / \text { system. temperature ratio }<4.5 . \text { heater head } \\
\text { temperature }<1300 \mathrm{~K} . \text { convertor efficiency }=\mathrm{f}(\text { Trat) }\end{array}$ \\
\hline Radiator & $\begin{array}{l}\text { Heat pipe with } \mathrm{C}-\mathrm{C} \text { facesheets. } 2 \text { sided. } 75 \% \text { effective area. } \\
6.4 \mathrm{~kg} / \mathrm{m} \text {. sink } 1 \text { emperature }=\mathrm{f}(\mathrm{AU})\end{array}$ \\
\hline PMAD & $28 \mathrm{Vdc}$ bus. $150 \mathrm{~W} / \mathrm{kg} .95 \%$ efficiency \\
\hline
\end{tabular}

In order to determine the most promising component technologies, several different representative concentrator configurations were compared. These included a parabolic, thin-film inflatable system having a total reflection/transmission (R/T) efficiency of $63 \%$, an areal density of $2 \mathrm{~kg} / \mathrm{m}^{2}$ (which includes the gas make-up system), and an Earth geometric concentration ratio (GCR) of 1600:1. The Earth GCR is defined as the ratio of the primary concentrator area to the receiver aperture area (or secondary entrance area) as required at I AU and provides a measure of the concentrator's overall surface accuracy. The theoretical maximum GCR for a solar concentrator at $1 \mathrm{AU}$ having a focal distance-to-diameter ( $\mathrm{f} / \mathrm{d}$ ) ratio of 1 is about $12000: 1$. This ratio varies with distance from the sun in relation to the subtended angle of the Sun relative to the concentrator. A second primary concentrator concept employing inflatable structure and a flat, fresnel reflector was assumed to have a combined R/T efficiency of $85 \%$, an areal density of $0.5 \mathrm{~kg} / \mathrm{m}^{2}$, and an Earth GCR of $1000: 1$. Three different secondary concentrator options were considered: no secondary, a reflective secondary, and a refractive secondary. The masses of the secondary concentrators were scaled based on previous designs, the refractive crystal having a mass of over four times that of the reflective option for the same entrance diameter.

The Stirling temperature ratio (Trat, defined as Thot/Tcold) and heater head temperature (Thot) were concurrently optimized for minimum system mass. Generally, higher temperature ratios relate to higher conversion efficiency (smaller primary concentrators) at the expense of lower waste heat rejection temperatures (larger radiators). Consequently, a mass optimized temperature ratio results from the trade-off of concentrator mass and radiator mass. Varying the heater head temperature yields a minimum system mass based on a balance of infrared cavity loss and Stirling efficiency. Higher temperatures result in greater receiver losses, but allow the Stirling to operate at higher efficiency (higher Trat) without adversely effecting radiator size. Like the temperature ratio optimization, the heater head temperature optimization also results from a compromise between concentrator mass and radiator mass. For this study, Stirling temperature ratio was limited to 4.5 and heater head temperature was limited to $1300 \mathrm{~K}$. 


\section{STUDY RESULTS}

Figure 4 illustrates the Stirling optimization process showing system mass as a function of Stirling temperature ratio for a Jupiter mission (5.2 AU) using a Fresnel primary and a refractive secondary. Local minimum mass points for each of three different heater head temperatures are indicated by asterisks. Higher temperatures result in greater optimum temperature ratios. The global minimum mass design point was achieved at a heater head temperature of $1150 \mathrm{~K}$ and a temperature ratio of 3.8 resulting in a system mass of $33.6 \mathrm{~kg}$. The optimum heater head temperature and temperature ratio varied greatly with mission destination (i.e. solar distance). For Mars, minimum system mass was achieved at a heater head temperature of $1300 \mathrm{~K}$, while a Pluto system resulted in a minimum mass heater head temperature of $600 \mathrm{~K}$. The key factor in determining the optimum heater head temperature was the size of the receiver aperture and the associated infrared losses. At near-Earth distances, the receiver aperture was relatively small so a high temperature cavity did not produce excessive losses. However, as the primary concentrator increased for greater solar distances, a corresponding increase in receiver aperture size necessitated a lower cavity temperature to control receiver losses.

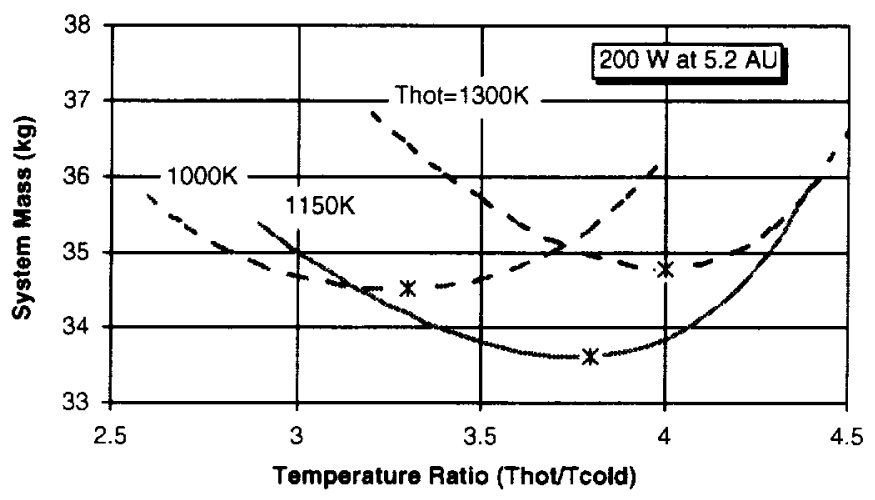

FIGURE 4. Stirling Mass Optimization for Jupiter Mission

A comparison of concentrator configurations for the 5.2 AU Jupiter mission is provided in Table 2. The Fresnel primary and refractive secondary combination resulted in the lowest system mass. The higher mass for the thin-film cases, was primarily a result of the $4 \mathrm{x}$ increase in areal density relative to the Fresnel. The Fresnel/refractive system also corresponded to the highest system efficiency, defined as the ratio of electric power produced to solar power collected by the primary. System efficiency was found to be a good indicator of system mass since the primary concentrator tended to be the dominant mass component. The primary concentrator was about $35 \%$ of the system mass at $5.2 \mathrm{AU}$, and beyond $10 \mathrm{AU}$, the mass fraction increased to greater than $50 \%$.

TABLE 2. Concentrator Comparison at $5.2 \mathrm{AU}$

\begin{tabular}{|l|l|c|c|c|c|}
\hline Primary & Secondary & Mass (kg) & Diam (m) & Thot (K) & Sys Eff (\%) \\
\hline Fresnel & None & 40.9 & 6.1 & 750 & 13.5 \\
\hline & Reflective & 34.4 & 5.6 & 1150 & 15.9 \\
\hline & Refractive & 33.6 & 5.3 & 1150 & 18.2 \\
\hline Thin-film & None & 90.2 & 6.0 & 900 & 13.9 \\
\hline & Reflective & 83.4 & 6.0 & 1150 & 13.9 \\
\hline & Refractive & 76.5 & 5.7 & 1150 & 1.5 .7 \\
\hline
\end{tabular}

The performance metrics assumed for the two primary concentrator options were chosen by projecting present day performance toward future systems. Uncertainty in those projections makes it appropriate to evaluate performance sensitivities. Figure 5 compares system mass versus primary diameter at $5.2 \mathrm{AU}$ with parametric variations in Earth GCR, areal density, and R/T efficiency. The reference point represents the baseline assumptions for the Fresnel primary: 1000:1 Earth GCR, $0.5 \mathrm{~kg} / \mathrm{m}^{2}$, and $85 \% \mathrm{R} / \mathrm{T}$ efficiency. In general, the Earth GCR and the R/T efficiency parameters have a greater influence on the primary diameter size. Conversely, the concentrator areal density has a dramatic effect on system mass. These same trends were consistent over the entire range of solar distances considered in the study. 


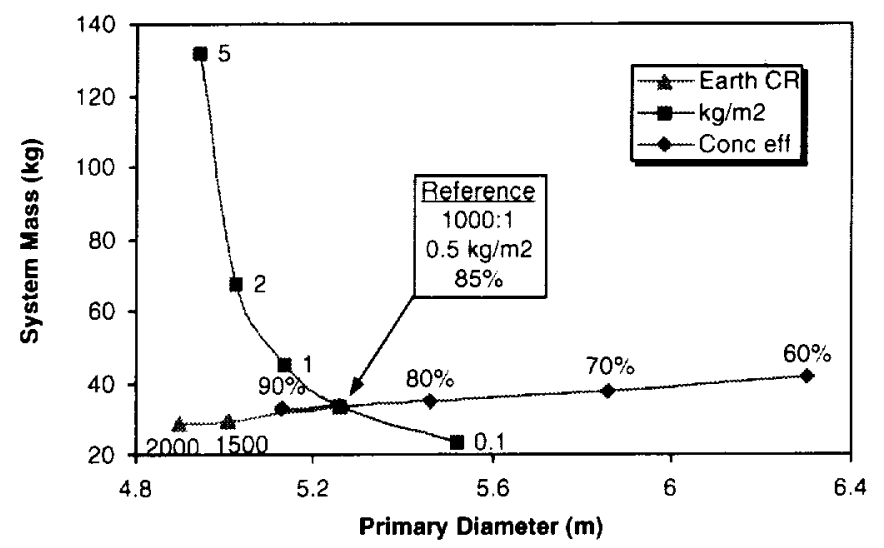

FIGURE 5. Primary Concentrator Sensitivity Analysis. $200 \mathrm{~W}$ at $5.2 \mathrm{AU}$

The variation in system mass and primary diameter with increasing solar distance is presented in Figure 6 . Since areal density was determined to be a key system mass driver, values from $0.1 \mathrm{~kg} / \mathrm{m}^{2}$ to $5 \mathrm{~kg} / \mathrm{m}^{2}$ were considered. Based on the entrance diameter and the corresponding mass of the refractive crystal, it was desirable to use a reflective rather than a refractive secondary for missions beyond $10 \mathrm{AU}$. Below $10 \mathrm{AU}$. reasonable system mass was achievable with primary concentrators of less than $10 \mathrm{~m}$ and areal densities of less than $2 \mathrm{~kg} / \mathrm{m}^{2}$. Systems for missions beyond $10 \mathrm{AU}$ required primary concentrators greater than $20 \mathrm{~m}$ and areal densities below $0.5 \mathrm{~kg} / \mathrm{m}^{2}$ in order to achieve reasonable system mass.

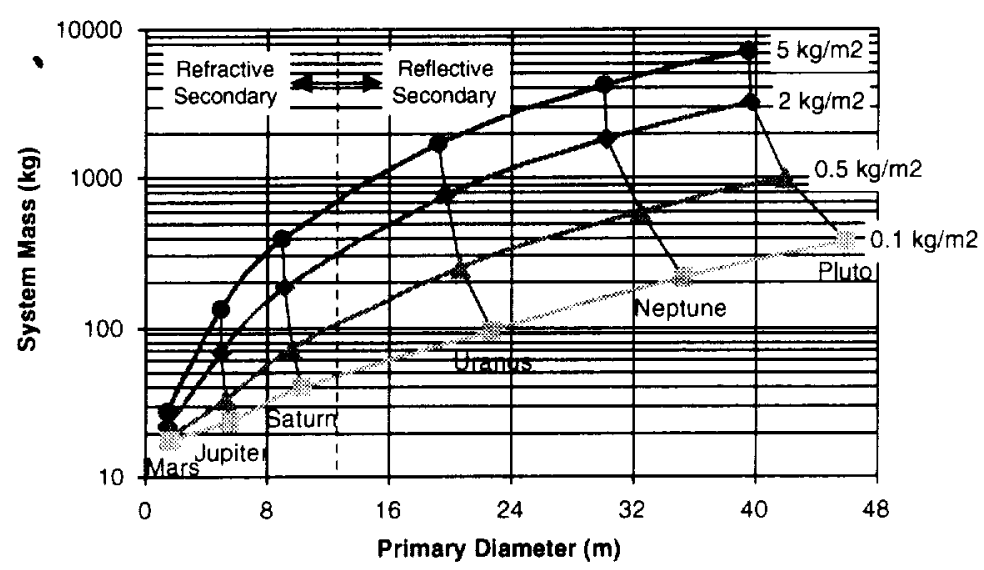

FIGURE 6. Performance Variations with Distance from Sun for 200 W Solar Stirling

\section{SYSTEM COMPARISONS}

Coincidentally, the $10 \mathrm{AU}$ breakpoint serves as a reasonable upper limit for this technology as compared to radioisotope power systems. Table 3 compares system performance of 200 watt solar Stirling power systems at 1.5 AU (Mars), 5.2 AU (Jupiter), and 9.5 AU (Saturn) with two different radioisotope options: ARPS and small RTG. The solar power systems utilize the Fresnel/refractive concentrator configuration and vary in specific power from just under $3 \mathrm{~W} / \mathrm{kg}$ for Saturn to almost $11 \mathrm{~W} / \mathrm{kg}$ for Mars. The radioisotope systems require two units to approach the 200 watt end-of-mission (EOM) requirement resulting in specific power levels between 4 and $5 \mathrm{~W} / \mathrm{kg}$. A 200 watt solar Stirling for Jupiter has about the same mass as two ARPS units providing 150 watts EOM. The ARPS configuration would require 6 GPHS modules for the two units, while the small RTGs would require a total of 12 GPHS modules. In reference to the size of the solar collector, the $5.3 \mathrm{~m}$ primary concentrator diameter for the Jupiter system is similar to one Tracking and Data Relay Satellite System (TDRSS) antenna. 
The natural decay of the radioisotope source causes a decrease in electrical power output with time. The EOM power and efficiency estimates for the radioisotope systems in Table 3 are based on the GPHS providing 232 watts per module after six years of operation (BOM thermal power from a GPHS module is 243 watts). Definition of the BOM power level for the solar systems requires further study. The large primary needed to collect power at the outer planets causes excessive power to be collected at Earth orbit. Some form of energy management would be required. Options include: 1) off-pointing of the primary, 2) adaptive focusing of the primary, 3) variable diameter shutter on the receiver aperture. or 4) a high temperature radiator for the receiver. An additional option might be to use a small solar panel for initial power and deploy the concentrator at further distances from the Sun.

TABLE 3. Comparison to Radioisotope Power Systems

\begin{tabular}{|c|c|c|c|c|c|}
\hline & $\begin{array}{c}\text { Solar } \\
\text { Stirling }\end{array}$ & $\begin{array}{l}\text { Solar } \\
\text { Stirling }\end{array}$ & $\begin{array}{l}\text { Solar } \\
\text { Stirling }\end{array}$ & $\begin{array}{c}\text { ARPS } \\
\text { AMTEC }\end{array}$ & $\begin{array}{c}\text { Small } \\
\text { RTG }\end{array}$ \\
\hline Distance $(\mathrm{AU})$ & 1.5 & 5.2 & 9.5 & \multicolumn{2}{|c|}{ variable - 6 yr life } \\
\hline EOM power (W) & 200 & 200 & 200 & 150 & 182 \\
\hline $\begin{array}{l}\text { EOM system } \\
\text { efficiency }(\%)\end{array}$ & 17.8 & 18.2 & 18.1 & 10.8 & 6.5 \\
\hline Total mass (kg) & 18.6 & 33.6 & 74.4 & 29.8 & 45.2 \\
\hline Sp power $(W / k g)$ & 10.7 & 5.9 & 2.7 & 5.0 & 4.0 \\
\hline Prim dia (m) & 1.6 & 5.3 & 9.7 & - & - \\
\hline
\end{tabular}

\section{CONCLUSION}

The results of this study indicate that a solar Stirling power system is a feasible alternative for deep space applications. The key technology elements include a lightweight primary concentrator, a high efficiency secondary concentrator, and a high efficiency Stirling convertor.

System mass and deployed area were characterized out to $40 \mathrm{AU}$. Various concentrator configurations were considered included Fresnel and thin-film primaries, and reflective and refractive secondaries. Earth geometric concentration ratio and reflection/transmission efficiency of the primary were found to have a major effect on concentrator deployed area. Concentrator areal density was a key system driver, having a dominant influence on overall system mass. The flexibility of the Stirling convertor to operate at variable heater head temperatures, depending on the mission destination, helped to control infrared losses and maintain high overall system efficiency.

The solar Stirling system compared favorably with other deep space power options. Mass was competitive with radioisotope power systems out to $10 \mathrm{AU}$. A 200 watt solar power system for Jupiter offered $18.2 \%$ system efficiency at a specific power of $5.9 \mathrm{~W} / \mathrm{kg}$, a modest improvement over projected ARPS performance without the complications brought on by nuclear sources.

\section{REFERENCES}

Herrera. L.. "The U.S. Department of Energy Advanced Radioisotope Power System Program." Proceedings of the $33^{\prime \prime}$ Intersocien Energ. Conversion Engineering Conference, 1998.

Kelly. C.E. and Klee. P.M. "RTG Performance on Galileo and Ulysses and Cassini Test Results," Proceedings of the Space Techology and Applications International Forum (STAIF-97), 1997.

Lockheed Martin Astronautics. “ARPS Quarterly Program Review, DOE Headquarters.” September 17, 1998.

Mason. L.. "Technology Projections for Solar Dynamic Power." Proceedings of the Space Technology and Applications Imernational Forum (STAIF-99), NASA/TM-1999-208851, 1999.

Schock, A.. Or. C.. and Kumar. V.. "Radioisotope Power System Based on Improved Derivative of the Existing Stirling Engine and Alternator." Proceedings of the Space Technology and Applications Intemational Forum (STAIF-99), 1999.

White. M.A., Qui. S.. Olan. R.W.. and Erbeznik. R.M., "Technology Demonstration of a Free-Piston Stirling Advanced Radioisotope Space Power System." Proceedings of the Space Technology and Applications Intemational Forum (STAIF99). 1999.

Wong. W.A. and Macosko. R.P, "Refractive Secondary Concentrators for Solar Thermal Applications." Proceedings of the $34^{\text {th }}$ Intersocien Energ. Conversion Engineering Conference. NASA/TM-1999-209379. 1999. 



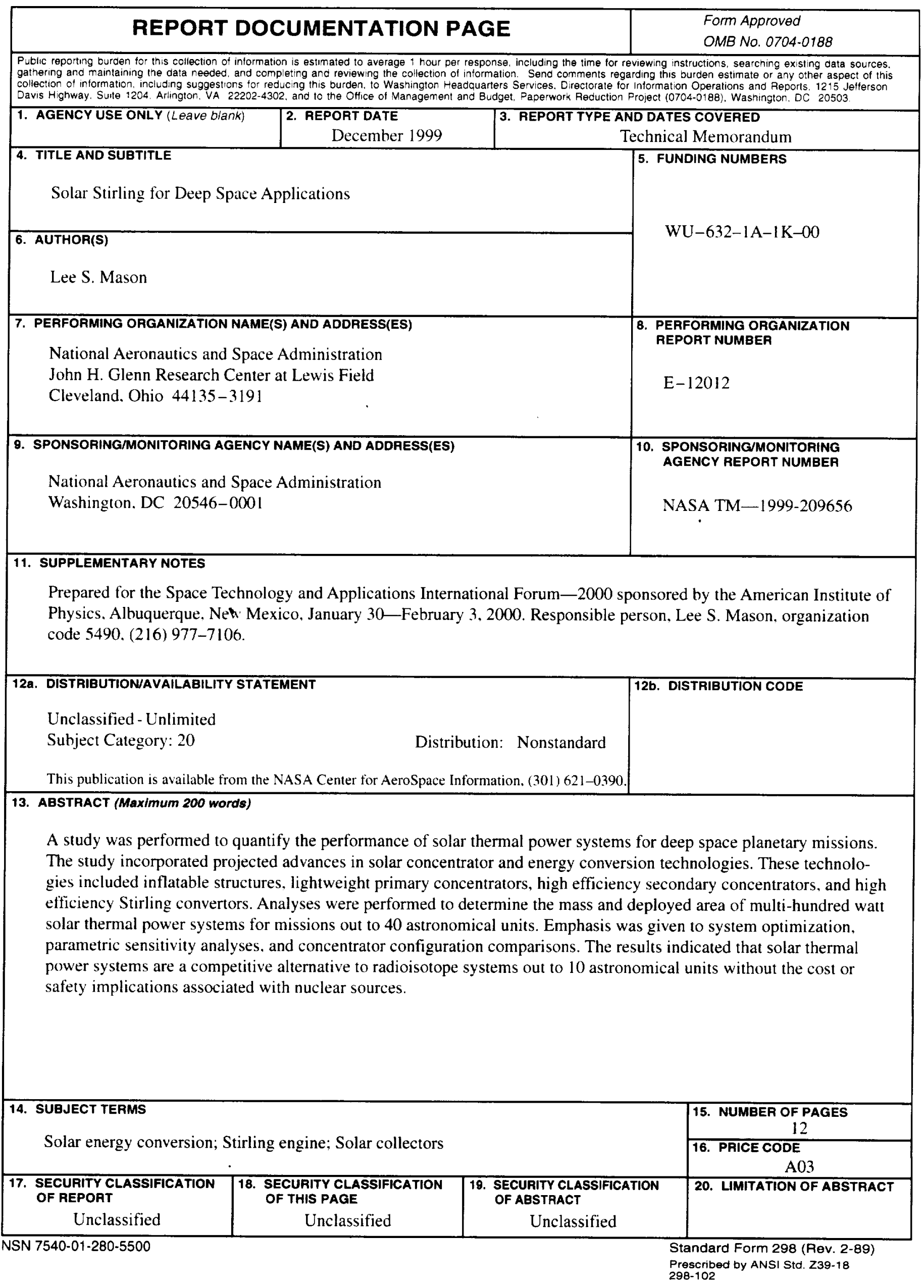

